\title{
Impact of supply chain risks on the completion for time of rural road projects in Bangladesh
}

\author{
Fatima Tuz Johora Thakur ${ }^{a^{*}}$ and Ferdowi Easmin ${ }^{b}$
}

${ }^{a}$ Ministry of Planning, Bangladesh ${ }^{b}$ Ministry of Agriculture, Bangladesh CHRON I C L E

\section{A B S T R A C T}

Article history:

Received: July 202019

Received in revised format: July

212019

Accepted: August 82019

Available online:

August 82019

Keywords:

Supply chain management

Supply chain risk

Rural road construction in

Bangladesh

Completion time of rural roads

project

\begin{abstract}
The volume of rural road construction projects has increased over the last decade in Bangladesh though these projects are experiencing failure in terms of time for completion. Therefore, this study focuses on nine risk factors specifically in case of Bangladesh. The objectives are to examine and quantify the contribution of supply chain risk factors on completion time of rural road projects and to assess the prioritization of identified risks. An insignificant number of researches have been performed on the effect of supply chain risks on completion time of rural roads in Bangladesh. To the best of authors' knowledge, the three factors such as, upper contract price, prolong rainy season and time of monitoring have not yet been used as independent variables in any research. A linear model has been drawn and the proposed model shows that upper contract price, delay of the site handover, delay of site materials mobilization, change of scope and prolong rainy season cause time overrun, whereas, time of monitoring, delay in payment and delay in submission of contract schedule did not have significant effect on time. These findings will help the government of Bangladesh take the necessary actions to complete the projects on time.
\end{abstract}

\section{Introduction}

Infrastructural development plays a vital role in the economic growth of developing countries (Project Management Institute, 2012). Infrastructure includes structures, systems, and facilities serving a country/city/area (Arthur \& Sheffrin, 2003). It also includes the services as well as facilities, which are necessary to continue the function of economy (Jeffrey, 2009). US National Research Council (1987) has defined public works infrastructure as the combination of technical physical structure of specific functional mode, such as roads, bridges, tunnels, water supply, electrical grids, etc. and operating procedures, management practices, and development policies. Due to lack of accessibility to rural roads, rural people remain poor (Lebo \& Schelling, 2001). To achieve the expected growth rate, Bangladesh depends on the improvement of transportation infrastructure (Alam, 2015). The transportation system of Bangladesh consists of roads, railways, inland waterways, ports, maritime shipping, and air transport. Among the different modes of transportation, road transportation has become the dominant mode, carrying over $70 \%$ of passengers and $60 \%$ of freight traffic. Realizing

* Corresponding author.

E-mail address: thakur.fatima@yahoo.com (F. T. J. Thakur) 
the importance of transport infrastructural development, the government of Bangladesh has been setting higher target on a regular basis compared with previous years in road construction projects (Alam, 2015). In Bangladesh, rural road covers more than $85 \%$ of the total road network of the country and it has increased agricultural production by as much as $32 \%$, and reduced transportation cost by 36\% (Federal Ministry for Economic Cooperation and Development, 2013).

The completion time also reaches further than what have been set out in the initial/approval stage (Mydin et al., 2013). It happens due to weakness in managing risk especially supply chain related (Wiguna \& Scott, 2005) as supply chain is the attributable character of the implementation stage of the construction project (Jagtap \& Kamble, 2015). The time overruns not only threaten the sector's potential to achieve the desired quality but also affect negatively on sustainability of existing infrastructure system (Adam et al., 2014). The Government of Bangladesh spends the development budget to implement ADP through implementation of development projects (Ahmed, 2010). The number of development projects included in ADP is increasing due to accelerate economic growth. During 2009-10 and 2013-14 the targeted number of projects were not completed and large number of completed projects were affected by time overrun (Table 1).

\section{Table 1}

Year wise comparison of time overrun of the projects included in ADP

\begin{tabular}{ccccc}
\hline $\begin{array}{l}\text { Financial } \\
\text { Year }\end{array}$ & $\begin{array}{l}\text { Total number of } \\
\text { projects included in } \\
\text { ADP (\%) }\end{array}$ & $\begin{array}{l}\text { Number of projects } \\
\text { were targeted for } \\
\text { completion }\end{array}$ & $\begin{array}{l}\text { Actual number of } \\
\text { projects that com- } \\
\text { pleted (\%) }\end{array}$ & $\begin{array}{l}\text { Time overrun in case of } \\
\text { completed projects (\%) }\end{array}$ \\
\hline $2013-14$ & $1366(2.86)$ & 298 & $233(78.19)$ & $114(49)$ \\
$2012-13$ & $1328(-)$ & 324 & $206(63.58)$ & $90(43)$ \\
$2011-12$ & $1340(3.72)$ & 285 & $199(69.82)$ & $79(40)$ \\
$2010-11$ & $1292(9.21)$ & 268 & $257(95.90)$ & $100(39)$ \\
$2009-10$ & 1183 & 232 & $195(84.05)$ & $51(26)$ \\
\hline
\end{tabular}

Source: Annual Progress Report of IMED (2015)

Annual progress report of IMED (2015) has identified the delay in procurement and land acquisition as the reasons for delay though the literature review shows the supply chain risk factors are the main causes of time and cost overrun of rural roads. An insignificant number of studies have been conducted on rural road construction project risk as well as impact of supply chain risk on the success of rural road construction project in public sector. For successful implementation of projects and to make the rural roads cost effective, large-scale project specific research is essential. This research has been conducted in view of this perspective.

\section{Related Work}

Delay in scheduling in case of construction projects is very common occurrence (Anastasopoulos et al., 2012) though factors vary from country to country. For instance, in Jordan owner's interference, inadequate experiences of contractors, financing and payment of the work are the top five reasons for the delay (Odeh \& Battaineh, 2002), whereas, in Thailand shortage of materials, delay in designing, late delivery of materials, inadequate site monitoring and slow work approval are the main reasons (Ogunlana et al., 1996). Dutta and Dutta (2015) found that poor quality of feasibility study, natural calamities, larger size of projects, involvement of hierarchy in different government organization, project location are the reasons of time overrun in Bangladesh. Halwatura and Ranasinghe (2013) found that variation order, poor estimation of cost, order common. Poor estimation of cost, unforeseen site conditions, political pressure during construction stage are the reasons of time overrun in Sri Lanka. Doloi et al. (2012) mentioned that the lack of sophistication leaded to inconsistent performance and continuously failed across all the key performance measures including time, cost and quality what was the key issue in the industry. Factor analysis and regression modelling were also used. All the factors were positively correlated with the impact of delay in the regression model. The fitted model is: Impact of delay $=-.853+.368$ (slow decision from owner) 
+.177 (consultant's and architect's reluctant for change) +.165 (poor labour productivity) +.299 (poor site management and supervision) +.325 (rework due to error).

\section{Research Design and Objectives}

The research aim is to capture the relationship between several supply chain associated risk factors with completion time of rural road in public sector and how these factors are managed in Bangladesh by using actual data. The objectives are to examine and quantify the contribution of supply chain risk factors on completion time of rural road projects and to assess the prioritization of identified risks.

\section{Survey Methodology}

Two completed projects named "Important Rural Infrastructure Development Project on Priority Basis" and "Union Road and Other Infrastructure Development Project" of The Local Government Engineering Department (LGED) have been selected for this study. Only 120 completed packages out of 137 packages of road construction in Narayangonj (Araihazar, Rupgonj, Bandar, Sonargaon) and Dhaka (Dohar, Savar, Keranigonj and Dhamrai) districts have been considered in the study. Data have been collected from project manager and contractors through both face-to-face (35\%) and telephone interview (65\%) during 20 March - 6 April 2016. In the study time of completion is being considered as dependent variables (Fig. 1) and measured by calendar days. Data for each road have been collected from the project annual report.

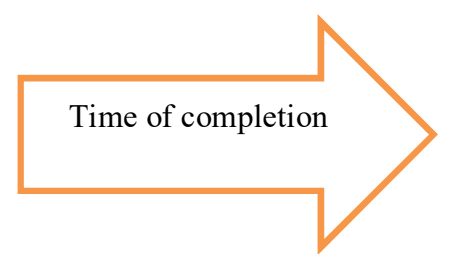

Delay in site handover, delay of site materials mobilization, upper contract price, delay in submission of contract schedule, changes in items, change of scope, delay in payment, prolong rainy season and time of monitoring.

Fig. 1. Dependent and independent variables selected in the study

The prepared questionnaires have been completed by the contractors and project managers. This is an explanatory, 'Ex post facto' and quantitative type of research which includes descriptive statistics, Pearson's correlation and linear multiple regression analysis. Selected sample sizes of 120 responses out of 137 were analyzed. Linear Regression Model has been used to measure the relationship between dependent and independents variables, and descriptive statistics like standard deviation has been used for obtaining the mean (Fig. 2)

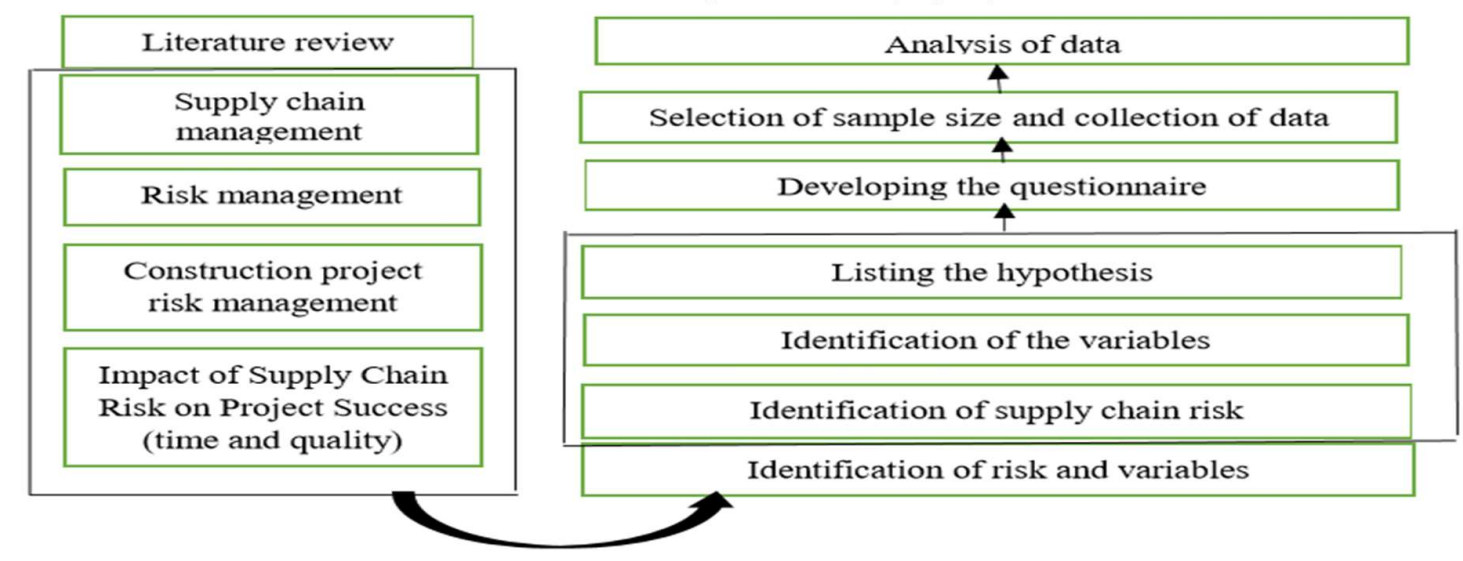

Fig. 2. Map of research process/framework of this study 
Among the respondents, the average age is 40 years and $14.5 \%$ of respondents completed $9-11$ packages, $22.2 \%$ of respondents completed $15-17$ packages and more than $5 \%$ respondents completed 18- more packages of construction in LGED. To ensure the accuracy/validity of data that has been collected through interview from the respondents has been verified from the official filed documents, which are being kept in the project office.

\section{Result and Discussion}

The Table 2 shows the descriptive statistics of dependent variable time for completion along with the independent variables.

Table 2

Descriptive statistics of dependent variable time for completion

\begin{tabular}{lccccc}
\hline Variables & Mean & Std. Deviation & Minimum & Maximum & Observation (N) \\
\hline Time for completion & 305.41 & 102.681 & 90 & 587 & 118 \\
Delay in site handover & 41.31 & 28.093 & 16 & 180 & 118 \\
Delay in site mobilization & 59.37 & 41.739 & 10 & 270 & 118 \\
Upper contract price & 158946.74 & 542055.656 & 47 & 3565229 & 118 \\
Delay in scope change & 34.03 & 23.928 & 12 & 120 & 118 \\
Delay in contract schedule & 27.01 & 16.698 & 7 & 120 & 118 \\
Delay for prolong rainy season & 28.70 & 15.130 & 15 & 65 & 118 \\
Delay in item changed & 13.01 & 6.966 & 7 & 35 & 118 \\
Times of monitoring & 2.03 & 0.470 & 1 & 3 & 118 \\
Delay in payment & 1.14 & 0.353 & 1 & 2 & 118 \\
\hline
\end{tabular}

Source: Field survey, 2015

Table 3

Correlations in case of dependent variables time for completion

\begin{tabular}{|c|c|c|c|c|c|c|c|c|c|c|c|}
\hline Variables & 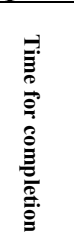 & 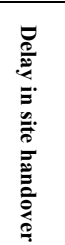 & 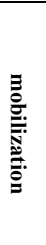 & 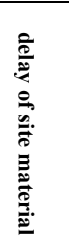 & 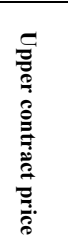 & 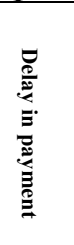 & 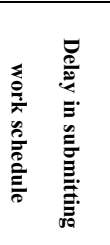 & 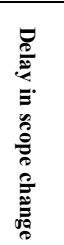 & 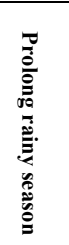 & 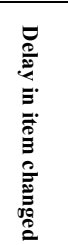 & 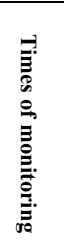 \\
\hline Time for completion & 1.000 & & & & & & & & & & \\
\hline Delay in site handover & .525 & 1.000 & & & & & & & & & \\
\hline $\begin{array}{l}\text { Delay of site material mobiliza- } \\
\text { tion }\end{array}$ & .545 & & & 1.000 & & & & & & & \\
\hline Upper contract price & .122 & -.087 & & -.038 & 1.000 & & & & & & \\
\hline Delay in payment & -.126 & -.136 & & -.068 & -.011 & 1.000 & & & & & \\
\hline $\begin{array}{l}\text { Delay in submitting work } \\
\text { schedule }\end{array}$ & 361 & .211 & & .637 & -.098 & .024 & 1.000 & & & & \\
\hline Delay in scope change & & .244 & & .237 & -.104 & .008 & .214 & 1.000 & & & \\
\hline Prolong rainy season & .344 & .166 & & .258 & .109 & -.094 & .283 & -.066 & 1.000 & & \\
\hline Delay in item changed & & .182 & & & .099 & -.174 & & & -.014 & 1.000 & \\
\hline Times of monitoring & .002 & .040 & & .117 & -.069 & -.030 & .017 & .138 & .106 & .170 & 1.000 \\
\hline \multicolumn{12}{|l|}{ Time for completion } \\
\hline Delay in site handover & $* .000$ & & & & & & & & & & \\
\hline Delay in site mobilization & $* .000$ & $* .000$ & & & & & & & & & \\
\hline Upper contract price & $\$ .095$ & .174 & & .343 & & & & & & & \\
\hline Delay in payment & $\$ .086$ & \$.071 & & .234 & .452 & . & & & & & \\
\hline $\begin{array}{l}\text { Delay in submitting work } \\
\text { schedule }\end{array}$ & $* .000$ & ${ }^{\circ} .011$ & & $* .000$ & .146 & .396 & & & & & \\
\hline Delay in scope change & $* .000$ & ${ }^{\ddagger} .004$ & & ${ }^{\ddagger} .005$ & .132 & .467 & ${ }^{\neq} .010$ & & & & \\
\hline Prolong rainy season & $* .000$ & ${ }^{\circ} .036$ & & ${ }^{\neq} .002$ & .120 & .155 & $* .001$ & .238 & . & & \\
\hline Delay in item changed & $* .000$ & ${ }^{\circ} .024$ & & $* .000$ & .142 & ${ }^{\circ} .029$ & $* .000$ & $* .000$ & .438 & & \\
\hline Times of monitoring & .493 & .334 & & .104 & .229 & .375 & .427 & $\$ .068$ & .127 & ${ }^{\circ} .033$ & \\
\hline Time for completion & 118 & 118 & & 118 & 118 & 118 & 118 & 118 & 118 & 118 & 118 \\
\hline Delay in site handover & 118 & 118 & & 118 & 118 & 118 & 118 & 118 & 118 & 118 & 118 \\
\hline Delay in site mobilization & 118 & 118 & & 118 & 118 & 118 & 118 & 118 & 118 & 118 & 118 \\
\hline Upper contract cost & 118 & 118 & & 118 & 118 & 118 & 118 & 118 & 118 & 118 & 118 \\
\hline Delay in payment & 118 & 118 & & 118 & 118 & 118 & 118 & 118 & 118 & 118 & 118 \\
\hline $\begin{array}{l}\text { Delay in submitting work } \\
\text { schedule }\end{array}$ & 118 & 118 & & 118 & 118 & 118 & 118 & 118 & 118 & 118 & 118 \\
\hline Delay in scope change & 118 & 118 & & 118 & 118 & 118 & 118 & 118 & 118 & 118 & 118 \\
\hline Prolong rainy season & 118 & 118 & & 118 & 118 & 118 & 118 & 118 & 118 & 118 & 118 \\
\hline Delay in item changed & 118 & 118 & & 118 & 118 & 118 & 118 & 118 & 118 & 118 & 118 \\
\hline Times of monitoring & 118 & 118 & & 118 & 118 & 118 & 118 & 118 & 118 & 118 & 118 \\
\hline
\end{tabular}

${ }^{*}$ Significant at 0.001 level $\left({ }^{*}<0.001\right),{ }^{\neq}$Significant at 0.01 level $\left({ }^{\neq}<0.01\right),{ }^{\circ}$ Significant at 0.05 level $\left({ }^{\circ}<0.05\right)$ and ${ }^{\S}$ Significant at 0.1 level $\left({ }^{\S}<0.1\right)$ 
Multiple $R$ is 0.722 which indicates large correlation between the predicted and observed values of outcome. So, it can be stated that the model predicts the observed data very well as $\mathrm{R}=1$ represents defines that the model perfectly predicts the observed data. Value of $R^{2}$ is 0.522 which expresses that the independents variables are account for approximately $52.2 \%$ of the variation in time for completion. 'Durbin-Watson test' tests whether residuals are correlated (Field, 2005). The value of 'Durbin-Watson test' is 1.273 , which is below 2, indicates that there is positive correlation between adjacent residuals. $\mathrm{F}$ ratio is 13.082 , significant at $\mathrm{p}<0.001$ which is more than 1 , indicates that regression model overall predicts time for completion significantly well. The mean square for regression and residual is calculated by dividing sum of squares by the degree of freedom. Table 3 exhibits the correlation matrix, which have been derived from Pearson correlation analysis for time for completion. There is no value more than 0.8 in both the correlation matrix, which expresses that there is no multi-co-linearity among the variables. The range of value from $0.5-0.7$, mentioned in red color means strong correlation, $0.3-0.49$ identified by yellow color means moderate correlation and $0.1-0.29$ mentioned by violet color indicates lower correlation. Significant at 0.001 level is expressed by $*(*<0.001)$, significant at 0.01 level is expressed through $\#(\#<0.01)$, significant at 0.05 level is expressed by ${ }^{\circ}\left({ }^{\circ}<0.05\right)$ and significant at 0.1 level is expressed through $\$$ $(\$<0.1)$. Table 3 shows that in majority cases correlation is lower between the variables.

Linear regression analysis for time for completion is described in Table 4 with the level of significance.

\section{Table 4}

Coefficients in case of dependent variable time for completion

\begin{tabular}{|c|c|c|c|c|c|c|c|c|}
\hline \multirow{2}{*}{\multicolumn{2}{|c|}{ Model }} & \multicolumn{2}{|c|}{$\begin{array}{l}\text { Unstandardized } \\
\text { Coefficients }\end{array}$} & \multirow{2}{*}{$\begin{array}{c}\text { Standardized } \\
\text { Coefficients } \\
\text { Beta }\end{array}$} & \multirow[t]{2}{*}{$\mathrm{t}$} & \multirow[t]{2}{*}{ Sig. } & \multicolumn{2}{|c|}{$\begin{array}{l}\text { 95.0\% Confidence Interval } \\
\text { for B }\end{array}$} \\
\hline & & $\mathrm{B}$ & Std. Error & & & & Lower Bound & Upper Bound \\
\hline \multirow{10}{*}{1} & (Constant) & 175.798 & 43.149 & & 4.074 & ${ }^{*} .000$ & 90.269 & 261.327 \\
\hline & Delay in site handover & 1.149 & .279 & .314 & 4.116 & ${ }^{*} .000$ & .596 & 1.702 \\
\hline & delay in site mobilization & .686 & .242 & .279 & 2.840 & ${ }^{\neq} .005$ & .207 & 1.165 \\
\hline & Upper contract price & 2.460 & .000 & .130 & 1.851 & $\$ .067$ & .000 & .000 \\
\hline & Delay in payment & -6.574 & 20.228 & -.023 & -.325 & .746 & -46.670 & 33.522 \\
\hline & Delay in submitting work schedule & -.185 & .569 & -.030 & -.325 & .746 & -1.312 & .942 \\
\hline & Delay in scope change & .838 & .325 & .195 & 2.576 & ${ }^{\circ} .011$ & .193 & 1.483 \\
\hline & Prolong rainy season & 1.621 & .504 & .239 & 3.219 & ${ }^{\ddagger} .002$ & .623 & 2.620 \\
\hline & Delay in item changed & 1.901 & 1.279 & .129 & 1.486 & .140 & -.635 & 4.437 \\
\hline & Times of monitoring & -24.486 & 15.130 & -.112 & -1.618 & .109 & -54.477 & 5.505 \\
\hline
\end{tabular}

\subsection{Upper Contract Price (UCP) $(b=2.460, p=0.067)$}

This value indicates that as contract price increases by one unit, time for completion increases by 2.460 units. Independent variable is measured in money but dependent variable is measured in days. This interpretation is true only if the effects of the other variables are held constant.

H1: Upper contract price is negatively related with the time for completion.

Therefore, null hypothesis is rejected. In case of higher contract price, the procuring entity has to adjust money from contingency fund. In such case, the contractor does not stop the work, as there is certainty of payment. They manage money and they are unable to buy, bring materials and have to pay the other cost timely. It slows the process indirectly. Enshassi et al. (2009) have also observed that a shortage of cash slows the progress when the contractors are unable to purchase the needed equipment/materials for work.

\subsection{Delay in Payment (DIP) $(b=-6.574, p=0.746)$}

This value indicates that time for completion is not statistically dependent on delay in payment. According to literature review, time for completion depends on delay of payment but the study design, used to generate the data, does not have sufficient power to detect that dependence. Independent variable is measured in BDT but dependent variable is measured in days. 
$\mathbf{H}_{2}$ : Delay in payment is positively related with the time for completion.

Therefore, the null hypothesis is rejected. This indicates that the delay of payment does not affect directly on the work of the contractors. There is certainty of payment as LGED is a government organization. Due to this, the contractor continues the construction work as they know they will get payment. The contractors have to borrow money from banks or others to continue the work. Ogunlana et al. (1996) have found similar result in their study on construction projects in Thailand.

5.3 Time of Monitoring (TOM) $(b=-24.486, p=0.109)$

This value indicates that time for completion is not statistically dependent on time of monitoring. The study design, used to generate the data, does not have sufficient power to detect that dependence.

H3: Time of monitoring is negatively related with the time for completion.

So, the null hypothesis is rejected. In the study, it is observed that monitoring does not have significant impact on early completion. It is seen that in the entire 120 packages site inspection book were present where the comments were written. The contractors sometimes are not interested to follow the comments. It depends on the relationship between the client and contractors.

\subsection{Changes in Items $(C I T)(b=1.901, p=0.140)$}

This value indicates that time for completion is not statistically dependent on changes in items. Time for completion is known to depend on changes in items but the study design, used to generate the data, does not have sufficient power to detect that dependence.

$\mathbf{H}_{4}$ : Changes in items is positively related with the time for completion.

Therefore, null hypothesis is rejected. If the cost of the items increases due to scarcity of any item or faulty design, the contractor changes the item in the middle of the work with the approval of the authority. It takes time for approval. Approximately in case of $42 \%$ packages the authority took at least 15 days to approve the item change. Thus, time for approval of item change does not have significant impact on completion of the construction work.

\subsection{Delay in Site Handover (DSH) $(b=1.149, p=.000)$}

This value indicates that as delay in site handover increases by one unit, time for completion increase by 1.149 units. Both variables are measured in days. This interpretation is true only if the effects of the other variables are held constant.

H5: Delay of the site handover is positively related with the time for completion.

Therefore, null hypothesis is accepted. Delay in site handover has great impact on the completion time of the construction. According to Ahmed (2010) land acquisition problem is the major reason of delay in site handover in Bangladesh. In his study among 70 respondents, 58 respondents agreed that delay in site handover due to land acquisition problem affect completion time. In this study, the findings are similar to Ahmed's findings, about 58.6\% delay occurred due to land acquisition.

5.6 Delay in Site Material Mobilization $(S S M M)(b=0.686, p=0.005)$

This value indicates that as delay in site mobilization increases by one unit, time for completion increase by 0.686 units. Both variables are measured in days. This interpretation is true only if the effects of the other variables are held constant. 
H6: Delay of site material mobilization is positively related with the time for completion.

Therefore, the null hypothesis is accepted. It means if materials are not brought at the construction site timely, it delays the completion period. Enshassi et al. (2009) have found that about $89.77 \%$ of total projects are delayed due to delay of site materials, whereas, Alaghbari et al. (2007) have indicated that this happens due to the mismanagement of the contractors. In this study, the findings are similar to Alaghbari et al.'s (2007) result. About $60 \%$ delay of site materials mobilization happens due to contractor's mismanagement.

\subsection{Delay in Submitting Work Schedule (DSWS) $(b=-0.185, p=0.746)$}

This value indicates that time for completion is not statistically dependent on delay in submitting work schedule. Time for completion is known to depend on delay in submitting work schedule but the study design, used to generate the data, does not have sufficient power to detect that dependence.

H7: Delay in submitting work schedule is positively related with the time for completion.

Therefore, the null hypothesis is rejected. The contractors submit their work schedule to the authority after signing the contract and they start construction work after getting the possession of the site. According to contract, site should be handover to the contractor within seven days of signing contract. Therefore, these two works are accomplished, simultaneously. The delay in site handover has more significant effect than delay of submitting work schedule on time for completion.

\subsection{Change in the Scope of Work $(C S W)(b=0.838, p=0.011)$}

This value indicates that as the scope of work increases by one unit, time for completion increases by 0.838 units. Both independent variable and dependent variables are measured in days. This interpretation holds only if the effects of the other variables are remained constant.

H8: Change in the scope of work is positively related with the time for completion.

So, null hypothesis is accepted. The scope of work changes in the middle of the work due to faulty design, local demand etc. If the number of scope changes increase, the time for completion of the construction package also increases. Chen and Kumaraswamy (1998)'s findings in Hong Kong are similar to the findings of this study.

\subsection{Prolong Rainy Season (PRS) ( $b=1.621, p=0.002)$}

This value indicates that if the rainy season increases by one unit, time for completion increase by 1.621 units. Both independent variable and dependent variables are measured in days. This interpretation is true only if the effects of the other variables are held constant.

H9: Prolong rainy season is positively related with the time for completion.

Therefore, the null hypothesis is accepted. Construction work is not carried out due to heavy rainfall during summer. If the rainy season starts early or it ends late, work can be delayed. Similar result is found by Al-Mamoni's (2000) where completions of projects have been strongly affected by bad weather.

\subsection{Linear Regression Model for Dependent Variable Time for Completion}

$\mathbf{Y}=175.798+2.460(\mathrm{UCP})-6.574(\mathrm{DIP})-24.486(\mathrm{TOM})+1.901(\mathrm{CIT})+1.149(\mathrm{DSH})+0.686$ $(\mathrm{SSMM})-0.185(\mathrm{DSWS})+0.838(\mathrm{CSW})+1.621(\mathrm{PRS})+\ldots \ldots \ldots \ldots . .+8.17\left(\mathrm{E}_{\mathrm{i}}\right)$

\section{Scatter plot Matrix}

According to Field (2005), scatter plot matrix shows the relationships between multiple pairs of variables. It helps to determine if there is linear correlation between multiple variables. According to Fig. 3, the scatter matrices indicate linear relationship between the dependent variable times for 
completion with related independent variables. Matrices show the strong or weak positive or negative correlation among the variables.

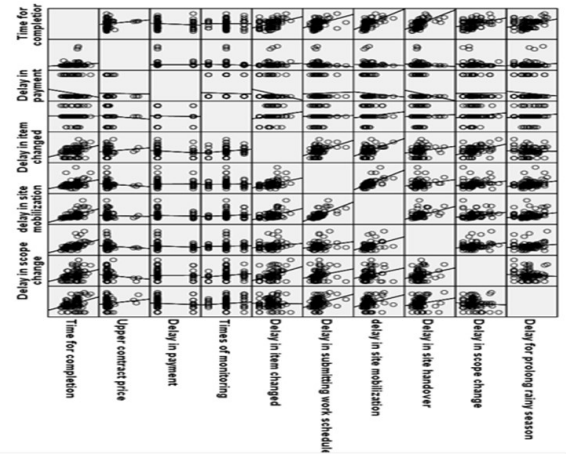

Fig. 3. Scatter matrices show linear relationships among dependent variable time for completion and the independent variables

\section{Identification and ranking of Risks}

In case of ranking risk, chance, impact and detection difficulty have been measured by the respondents. Likert Scale (1 to 5) has been used to indicate the severity. Measuring scale of chance, impact and detection difficulty: Negligible: 1, Minor: 2, Moderate: 3, Serious: 4, and Critical: 5 . The averages of chances, impact and detection difficulty mentioned by the 120 respondents have been placed in Table 5 to measure the rank of the identified risks.

\section{Table 5}

Ranking of risk, response plan, control measures (Source: Field survey, 2015)

\begin{tabular}{|c|c|c|c|c|c|}
\hline Risk Item & Chance & Impact & Detection Difficulty & \multicolumn{2}{|c|}{ Rank } \\
\hline 1 & 2 & 3 & 4 & $5=2 * 3$ & $6=2 * 3 * 4$ \\
\hline 1.Delay in site handover & 3.66 & 4.20 & 3.78 & 15.37 & 60.86 \\
\hline 2.Delay of drawing & 3.44 & 3.27 & 3.65 & 11.25 & 42.00 \\
\hline 3.Submission of work schedule & 2.30 & 2.45 & 2.45 & 5.64 & 13.45 \\
\hline 4.Delay of site materials mobilization & 3.32 & 3.43 & 3.73 & 11.39 & 42.13 \\
\hline 5.Slow approval & 3.68 & 3.23 & 3.90 & 11.89 & 49.25 \\
\hline 6.Change of scope & 3.81 & 3.27 & 3.87 & 12.46 & 50.53 \\
\hline 7.Lower contract price & 3.68 & 3.4 & 3.84 & 12.52 & 49.94 \\
\hline 8. Upper contract price & 3.23 & 2.78 & 3.45 & 8.98 & 30.99 \\
\hline 9.Delay of payment & 3.07 & 3.18 & 2.98 & 9.76 & 32.04 \\
\hline 10.Shortage of manpower and equipment & 3.71 & 3.42 & 3.86 & 12.69 & 51.03 \\
\hline 11.Prolong rainy season & 3.72 & 3.73 & 3.93 & 13.91 & 55.01 \\
\hline 12. Lack of monitoring & 3.40 & 3.36 & 3.85 & 11.42 & 45.83 \\
\hline 13.Lack of action taken after monitoring & 3.65 & 4.08 & 3.76 & 14.89 & 55.67 \\
\hline
\end{tabular}

The risk matrix prioritizes risks for further quantitative assessment or response planning (PMI, 2013). Fig. 4 shows the risk matrix where probability and impact are shown in X-axis and Y-axis. Risk can be lower, moderate and higher category, which have been expressed by green, yellow and red color. The severity up to 5 means less risky, area from 6 to 12 indicates moderately risky and area 13 to 25 is highly risky zone.

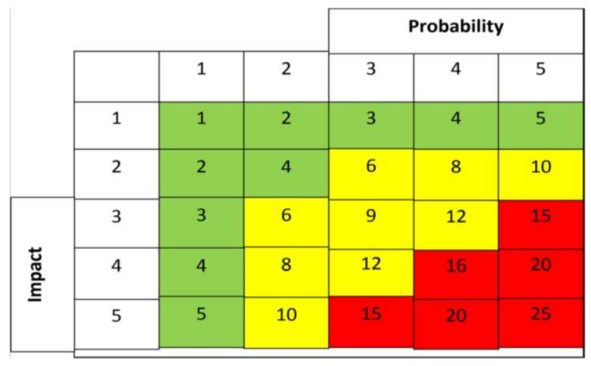

Fig. 4. Risk matrix 
According to respondents, delay in site handover has severe effect (15.37) on time for completion. Similarly, in India, majority projects of national highway delayed due to land acquisition (Rajeswari, 2014). Both Kartam (2001) and El-Sayegh (2008) found that land acquisition is moderately risky. The respondents of this study have mentioned scope change (12.46), shortage of manpower and equipment (12.69) are highly risky but delay in payment (9.76) is moderately risky for delay. El-Sayegh (2008) has shown that in UAE, severity of these two risks are scope change (11.38), delay of payment (11.18) are moderately but shortage of manpower and equipment is highly risky (12.37). Kartam \& Kartam (2001) has found that scope of work is moderately but delayed payment is highly risky (Appendix B). This study has found that lower contract price is riskier (12.52) than upper contract price (8.98). Mahamid (2013) has found in Palestine that high competition of bid is highly risky. This study has found that delay of drawing (11.25), delay in site material mobilization (11.39), slow approval (11.89) and time of monitoring (11.42) are moderately risky. Mahamid (2013) has also found the similar result though El-Sayegh (2008) has found that site material mobilization (12.8), slow approval (12.32) are highly risky but delay of drawing (10.12) is moderately risky.

\section{Conclusion}

This study has analysed the effect of supply chain risks on rural road construction project mainly from time perspective and how these risks were being prioritized using the available evidence from the People's Republic of Bangladesh. Selected sample size is 120 which has been calculated when the population size is 137 which is representative and reflective in terms of population size. Quantitative analysis based on multiple regression methods indicate that most of the Hypotheses were supported (i.e., delay in site handover, delay in site material mobilization, changes in scope of work prolong rainy season) indicate that they have significant impact on time for completion. The limitations of the study are 120 packages of two rural road projects have been considered in the study and only project managers and contractors are considered as respondents. It would be better if designers, consultants and local project authority were included as respondents in the study.

\section{Acknowledgements}

The authors are grateful to the Government of People's Republic of Bangladesh for proving the opportunity of studying in the UK. We are also grateful to Local Government Engineering Department (LGED) as all the data were provided by this organization. The first author is also indebted to her supervisor for the supervision. His guidance, encouragement and support helped shape this research significantly.

\section{References}

Adam, A., Josephson, P. E., \& Lindahl, G. (2015). Implications of cost overruns and time delays on major public construction projects. In Proceedings of the 19th International Symposium on Advancement of Construction Management and Real Estate (pp. 747-758). Springer, Berlin, Heidelberg.

Ahmed, S. (2010). Problems of ADP implementation in Bangladesh: an analytical review (Doctoral dissertation, BRAC University).

Alam, K. (2015). Strategy for Infrastructure Sector Background Paper for the Seventh Five Year Plan.

Alaghbari, W. E., Razali A. Kadir, M., Salim, A., \& Ernawati. (2007). The significant factors causing delay of building construction projects in Malaysia. Engineering, Construction and Architectural Management, 14(2), 192-206.

Al-Momani, A. H. (2000). Construction delay: a quantitative analysis. International journal of project management, 18(1), 51-59.

Arthur, S., \& Sheffrin, S. M. (2003). Economics: Principles in action'. Upper Saddle River, New Jersey 07458: Pearson Prentice Hall. 
Anastasopoulos, P. C., Labi, S., Bhargava, A., \& Mannering, F. L. (2011). Empirical assessment of the likelihood and duration of highway project time delays. Journal of Construction Engineering and Management, 138(3), 390-398.

Chan, D. W., \& Kumaraswamy, M. M. (2002). Compressing construction durations: lessons learned from Hong Kong building projects. International journal of project management, 20(1), 23-35.

Doloi, H., Sawhney, A., Iyer, K. C., \& Rentala, S. (2012). Analysing factors affecting delays in Indian construction projects. International journal of project management, 30(4), 479-489.

Dutta, A., \& Dutta, P. (2015). Causes of time and cost overruns in transportation sector projects in Bangladesh. International Journal of Economics and Management Studies, 2(4), 15-17.

El-Sayegh, S. M. (2008). Risk assessment and allocation in the UAE construction industry. International journal of project management, 26(4), 431-438.

Enshassi, A., Al-Najjar, J., \& Kumaraswamy, M. (2009). Delays and cost overruns in the construction projects in the Gaza Strip. Journal of Financial Management of Property and Construction, 14(2), 126-151.

Federal Ministry for Economic Cooperation and Development. (2013). Improving Rural Transport Infrastructure: experience from Bangladesh. Bonn: Federal Ministry for Economic Cooperation and Development.

Field, A. (2005). Discovering Statistics Using SPSS. $2^{\text {nd }}$ edition. Sage Publication Ltd.: London.

Halwatura, R. U., \& Ranasinghe, N. P. N. P. (2013). Causes of Variation Orders in Road Construction Projects in Sri Lanka. ISRN Construction Engineering, 1, 20-27.

Implementation Monitoring and Evaluation Division (IMED). ADP Progress Report 2014-15. Agargaon: IMED.

Jagtap, M., \& Kamble, S. (2015). Evaluating the Modus Operandi of Construction Supply Chain using Organization Control Theory. International Journal of Construction Supply Chain Management, 5(1), 7782.

Jeffrey, F. (2009). What in the world is infrastructure. PEI Infrastructure Investor (July/August), 30-32.

Kartam, N., \& Kartam, S. (2001). Risk and its management in the Kuwaiti construction industry: A contractors' perspective. International Journal of Project Management, 19(6), 325-335.

Lebo, J., \& Schelling, D. (2001). Design and appraisal of rural transport infrastructure: ensuring basic access for rural communities (Vol. 23). World Bank Publications.

Mahamid, I. (2013). Common risks affecting time overrun in road construction projects in Palestine: Contractors' perspective. Australasian Journal of Construction Economics and Building, 13(2), 45-53.

Mydin M.A.O., Sani, N. M., Taib, M., \& Alias N. M. (2013). Imperative Causes of Delays in Construction Projects from Developers' Outlook. MATEC Web of Conferences.

Odeh, A. M., \& Battaineh, H. T. (2002). Causes of Delay: traditional contract. International Journal of Project Management, 20(1), 67- 73.

Ogunlana, S. O., Promkuntong, K., \& Jearkjirm, V. (1996). Construction delays in a fast-growing economy: comparing Thailand with other economies. International Journal of Project Management, 14(1), $37-45$.

Project Management Institute. (2013). A Guide to the Project Management Body of Knowledge. $5^{\text {th }}$ ed. Atlanta: Project Management Institute Inc.

Project Management Institute. (2012). Study on Project Schedule and Cost Overrun. Retrieved from http://www.pmi.org.in/downloads/PMI_KPMG_2013.pdf [Accessed on $01 \mathrm{March}, 2016$ ].

Rajeswari, P. (2014). Land acquisition and rehabilitation - a great challenges to PPP projects. International Journal of Commerce, Business and Management, 3(6), 858- 866.

US National Research Council. (1987). Infrastructure for the 21st Century. Washington D.C.: National Academy Press.

Wiguna, P. A. and Scott, S. (2005). Nature of the Critical Risk Factors Affecting Project Performance in Indonesian Building Contracts. In Proceedings of the 21st Annual ARCOM Conference, 2005, SOAS, University of London (pp. 225-35). London: Association of Researchers in Construction Management, London.

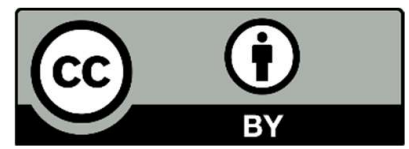

(C) 2020 by the authors; licensee Growing Science, Canada. This is an open access article distributed under the terms and conditions of the Creative Commons Attribution (CC-BY) license (http://creativecommons.org/licenses/by/4.0/). 